\title{
DIREITO, MOBILIZAÇÃO SOCIAL E MUDANÇA INSTITUCIONAL*
}

\section{Cristiana Losekann}

Universidade Federal do Espírito Santo (UFES), Vitória - ES. E-mail: cristianalosekann@gmail.com

\section{Luiza Duarte Bissoli}

Universidade Federal do Espírito Santo (UFES), Vitória - ES. E-mail: luizabissoli@gmail.com

DOI: $10.17666 / 329403 / 2017$

A relação entre os movimentos sociais e o direito tem animado o debate acadêmico há bastante tempo nos Estados Unidos e também em alguns países europeus. Parte do vigor do debate deveu-se a certo tensionamento entre aqueles que eram entusiasmados com as estratégias judiciais, sobretudo nas décadas de 1950 e 1960 nos Estados Unidos, e aqueles que compunham os Critical Legal Studies, os quais, contrariamente, desaconselharam movimentos sociais a realizarem o litígio estratégico como forma de atingir seus objetivos. Parte da explicação desse tensionamento está nas diferentes interpretaçóes produzidas por esses estudiosos sobre

* Versão preliminar apresentada no ST12, "Instituiçôes judiciais, política e moralidades na democracia", 37º Encontro Anual da Anpocs. Agradecemos a todos os colaboradores (suas sugestóes, comentários e críticas), em especial a Paulo M. Araújo pelo apoio nas tabelas. os efeitos do litígio estratégico ${ }^{1}$ (McCann, 1991; Polleta, 2000). Os primeiros, entusiasmados com o aumento do acesso às Cortes naquele contexto, depositaram muitas expectativas de mudança institucional e social na via litigância. Os segundos defenderam, entre as décadas de 1970 e 1990, o oposto. Argumentaram que as instituiçóes dificilmente mudam através dos tribunais e que os grupos sociais mais excluídos ou marginalizados não teriam os recursos necessários para usar esse tipo de estratégia.

Nesse sentido, a Legal Mobilization Theory (Teoria da Mobilização Legal - TML) trouxe como proposta equilibrar e complexificar esse debate, observando aspectos mais sutis do litígio estratégico. Também apresentou uma visão mais realista sobre o que se pode esperar acerca dos efeitos em termos de mudanças institucionais e sociais - aconselhando uma expectativa mais modesta sobre a capacidade de mudarmos as instituiçóes ou a sociedade, seja 
qual for o tipo de repertório de ação coletiva empregado. Seria preciso encarar o fato de que essas mudanças não ocorrem facilmente.

Essa perspectiva ampliou o espectro de análise incorporando elementos não institucionais e mais distantes dos atores tradicionais do direito. Segundo McCann (1991), a análise da lei, longe das iniciativas oficiais, constitui-se na maior contribuição da TML. Sendo assim, reunindo a agenda de estudos das teorias dos movimentos sociais (sobretudo a perspectiva do contentious politics) e da sociologia do direito, esse debate tem contribuído para entendermoscomo normase práticaslegais usadas por movimentos sociais podem gerar efeitos sobre aspectos da mudança social e institucional e, além disso, interferir nas próprias dinâmicas de mobilização.

A maior parte dos estudos sobre efeitos de estratégias judiciais enfatizaram (e ainda enfatizam) efeitos diretos, de curto prazo, relativos às demandas específicas de açóes legais formais, ou efeitos diretos de longo prazo, institucionais, como o surgimento de precedentes, novamente a partir de açōes legais formais. A grande inovação da TML é investigar os efeitos indiretos mais difusos e aqueles que se refletem sobre a própria mobilização social, algo como o que Galanter (1983) chamou de efeitos "irradiadores".

No Brasil, esses estudos sáo muito recentes. Seja pelo viés da participação, seja pela relação entre sociedade civil e Estado ou pela teoria dos movimentos sociais, pouco se estudou sobre as dinâmicas das interações entre as instituições de Justiça e a ação coletiva contestatória da sociedade. Precursora nessa agenda de pesquisa, Débora Alves Maciel é praticamente a única a pesquisar sobre isso no país (Maciel, 2011; Maciel e Prata, 2011). Outros estudos que trataram tangencialmente do tema enfatizaram mais a perspectiva da chamada "judicialização da política", com forte teor normativo, conforme argumentaram Maciel e Koerner (2002). A agenda propriamente da legal mobilization ainda precisa ser constituída enquanto debate teórico e com sistemáticas pesquisas empíricas no país. Este artigo pretende colaborar para a formação dessa agenda de pesquisa em nosso país. ${ }^{2}$

A contribuição que aqui apresentamos visa, também, trazer aspectos ainda não (ou pouco) conside- rados no debate internacional sobre as consequências do uso de estratégias judiciais. Partimos de dados empíricos e retornamos à teoria para oferecer elementos que contribuam para uma caracterização de tipos diversos de efeitos, quais sejam: efeitos que alteram ou incrementam os próprios processos de mobilização social e efeitos sobre as instituiçōes.

Efeitos estáo relacionados, conforme argumentou McCann (2010), às dinâmicas contingenciais pertinentes aos casos empiricamente estudados, mas nos permitem vislumbrar mecanismos recorrentes em outros contextos. Sendo assim, vamos apresentar cada um desses efeitos através da análise de diferentes casos em sessóes separadas no texto.

O artigo está estruturado da seguinte forma: após a explanação de aspectos metodológicos que caracterizam as pesquisas envolvidas, apresentamos o debate teórico e conceitual necessário a partir da legal mobilization, definindo a mobilização do direito e apresentando as principais linhas argumentativas sobre as consequências da constituição desse tipo de repertório. Nas sessóes seguintes, analisamos cada um dos efeitos que queremos apresentar examinando casos empíricos específicos. Os efeitos sobre processos de mobilizaçáo social são analisados a partir do estudo de um conjunto de conflitos ambientais no Rio de Janeiro e no Espírito Santo, com o uso do método etnográfico. Os efeitos sobre ressignificaçốes de enquadramentos (frames) legais existentes são explicitados através da observaçáo dos tipos de conflito para os quais a lei ambiental está sendo mobilizada, tendo em vista nosso banco de dados das Açôes Civis Públicas na cidade do Rio de Janeiro e no Estado do Espírito Santo. Por fim, a análise dos impactos da mobilização do direito sobre as instituiçôes é construída tendo em vista o caso da Campanha por um Brasil Livre de Transgênicos (CBLT).

\section{Metodologia}

Os dados apresentados neste artigo constituem alguns achados oriundos de duas pesquisas finalizadas e desenvolvidas como partes de uma agenda maior do nosso grupo de pesquisas, cujo foco é investigar o uso de estratégias judiciais como repertório de açấo coletiva de movimentos sociais. 
Além das pesquisas específicas, temos realizado um trabalho contínuo de acompanhamento das ações judiciais de relevância às causas coletivas, através de um observatório. ${ }^{3}$

Os dados empíricos apresentados aqui correspondem a resultados secundários de uma pesquisa que investigou o uso do instrumento da Ação Civil Pública (ACP) e sua relação com outras formas de ação coletiva nos conflitos ambientais na cidade do Rio de Janeiro e no Estado do Espírito Santo, e também de outra pesquisa, de mestrado, que analisou, no contexto da Campanha por um Brasil Livre de Transgênicos, o uso da ACP e da Ação Direta de Inconstitucionalidade. ${ }^{4}$

Cumpre dizer que a investigação acerca dos efeitos desse tipo de repertório náo se constituiu em objetivo primeiro de análise, contudo, os achados de pesquisa são suficientemente relevantes para contribuírem com esse debate.

Ambas as pesquisas utilizaram abordagens multimétodos, combinando o levantamento dos litígios e, posteriormente, a seleção e exame de alguns casos, etapa em que foram identificados os atores e os processos de ação coletiva envolvidos. A escolha dos casos deveu-se, principalmente, ao fato de apresentarem múltiplos atores e serem viáveis para a observação direta, através de técnicas tais como a observação participante e entrevistas. Ambas as pesquisas já tiveram seus dados principais apresentados em outras publicaçôes; não queremos, portanto, apresentar redundâncias (Losekann, 2013). Sendo assim, nos limitaremos a apresentar os dados inéditos realizando referência aos dados já publicados.

Assim, uma pesquisa levantou e analisou 793 ACPs impetradas no Estado do Espírito Santo e na cidade do Rio de Janeiro na área ambiental. ${ }^{5}$ Os dados foram produzidos a partir da coleta e da leitura dos registros das açôes judiciais e através da realização de entrevistas semiestruturadas com lideranças que fazem uso de estratégias judiciais.

Já a outra pesquisa levantou litígios envolvendo transgênicos, com recorte temporal de 1998 a 2012, nos sites oficiais do Superior Tribunal de Justiça (STJ), do STF (Supremo Tribunal Federal) e do Tribunal Regional Federal da $1^{\text {a }}$ Regiáo (TRF1). ${ }^{6}$ A partir da análise de conteúdo dessas ações, da realização de entrevistas semiestruturadas com atores ligados aos conflitos e da leitura de fon- tes secundárias, foram produzidos dados quanti- $\mathrm{e}$ qualitativos. A análise desses dados mapeou uma sequência de açóes judiciais que tiveram efeitos institucionais importantes sobre a legislação dos transgênicos. Para essas análises, optamos pela realização de uma descrição processual e causal da constituição da mobilização, e, para evidenciar os efeitos institucionais, a ênfase recairá sobre os dados das ações judiciais que serão citadas ao longo da explicação. A descrição foi construída, ainda, com a confrontação dos dados coletados em fontes secundárias, tais como publicaçóes oficiais e não oficiais, e entrevistas formais e conversas informais com atores que participaram dos litígios analisados.

Para o estudo dos casos de efeitos sobre a mobilização, realizamos ainda um acompanhamento e observações com atenção etnográfica de alguns conflitos onde se fazia necessário compreender de forma mais detalhada os processos de interação entre atores. Os conflitos que foram acompanhados de forma específica são fundamentalmente entre comunidades de pescadores e outras comunidades que vivem em regióes afetadas por grandes empreendimentos no Espírito Santo e no Rio de Janeiro. ${ }^{7}$ Esses dados foram fundamentais para compreender os efeitos dos litígios sobre a mobilizaçáo e sobre os atores. Os mesmos serão expostos na segunda sessão do artigo.

Parte dos achados proporcionados pelas pesquisas relacionam-se aos desenhos das pesquisas e da consequente forma como ocorreram as coletas de dados. Esta é uma nota metodológica importante. Em ambas as pesquisas, a estratégia de coleta de dados buscou levantar os litígios, ou seja, as açóes judiciais dentro dos temas predefinidos. Isso proporcionou uma observação mais complexa da questâo investigada e, por conseguinte, foi percebida uma ampla gama de atores que usam estratégias legais. Isso nos indicou a necessidade de uma análise qualitativa para certos casos e aspectos - estratégia investigativa textualmente recomendada por McCann (1991, p. 232) em suas reflexóes metodológicas. Se tivéssemos desde o início nos circunscrito às açóes propostas por movimentos sociais enquanto atores predefinidos, buscando açóes ajuizadas somente por associações civis como define a legislação brasileira, não teríamos capturado diversos casos onde atuam 
outros atores, tais como a Defensoria Pública e o Ministério Público. Dessa forma, teríamos perdido de vista o efeito mobilizador que será apresentado como parte de nossa argumentação.

\section{Elementos teóricos para analisar interaçóes entre os movimentos sociais e o direito}

Em 2006, uma obra substancial foi providenciada pela The International Library of Essays in Law and Society com um propósito: reunir os principais trabalhos já publicados sobre o direito e os movimentos sociais com base em perspectivas interdisciplinares. O organizador da obra, Michel McCann (2006b), explicitou na introdução do livro um problema e, ao mesmo tempo, um desafio colocado para essa temática de investigação. Ele argumentou que os dois campos de conhecimento que trataram do tema foram os estudos sociolegais e os estudos sobre movimentos sociais, mas, embora ambos tenham dado a sua contribuição, ainda permaneciam campos apartados e sem uma agenda comum de pesquisa.

Na década de 1990, a perspectiva da legal mobilization agregou as literaturas dos movimentos sociais e dos estudos legais (McCann, 2006b). Assim, essa área de estudos ganhou em termos analíticos a capacidade de compreender uma série de aspectos que antes eram negligenciados por uma ou outra abordagem.

Uma das principais contribuições nesse sentido foi a ampliação da conceitualizaçáo do direito (law), que foi definido de forma mais ampla, agregando várias dimensões, atores, instituiçôes, significados e espaços sociais. $\mathrm{O}$ foco interpretativo sobre discursos e práticas legais propôs compreender a lei como parte significativa da vida cotidiana das pessoas, as quais, em muitos sentidos, agem tendo como referência a lei ou as instituições judiciais. Mas, além de princípios normativos, o direito também foi concebido como fonte de recursos estratégicos que oportunizam e/ou constrangem a ação, definidos como "estruturas de suporte" (EPP, 1998) ou "oportunidades legais" (Kitschelt, 1986). Na medida em que possuem um papel constitutivo em sustentar hierarquias sociais, as leis ou instituiçóes judiciais criam constrangimentos e também oportunizam estratégias potenciais que podem ser acionadas nas lutas sociais.
Criando uma espécie de genealogia da TML, McCann (1991) identificou três conjuntos iniciais de estudiosos que poderiam ser diferentemente conectados à essa perspectiva. Um conjunto seria composto por estudos que investigaram o litígio estratégico, mas não aqueles ligados às causas coletivas, ficando limitados a indivíduos e disputas privadas (Black, 1973; Zemans, 1982, 1983; Lempert, 1976). Posteriormente, o autor identificou o deslocamento dessas análises para movimentos sociais e causas coletivas (Handler, 1978; Milner, 1986; Scheingold, 1974). E, finalmente, um terceiro grupo que náo estaria exatamente alinhado com o modelo da legal mobilization, embora apresente, ainda assim, de forma indireta, aspectos que colaboram com tal modelo analítico (Galanter, 1983; Schneider, 1986; Brigham, 1987; Crenshaw, 1988; Delgado et al., 1985; Minow, 1987).

Para McCann (1991), "a análise da lei longe das iniciativas oficiais é a maior contribuição da TML”, e, na definição básica de Zemans (1983, p. 700), "O direito é mobilizado quando um desejo ou vontade é transformado em uma demanda ou afirmação de direitos”. Mobilizar o direito não é só usar estrategicamente a lei, envolve interaçóes com atores do campo jurídico e implica a constituição de um repertório específico de ação coletiva.

A especificidade da mobilização do direito está na construção de um tipo de repertório de ação que atravessa as instituiçóes jurídicas judiciais, evidenciando, assim, a dimensão da juridicidade nas reivindicaçóes sociais em questão. Esse repertório estabelece interaçóes que conectam múltiplos atores, instituiçóes e campos (Rucht, 2008) - inclusive os judiciais. O que constitui a juridicidade da mobilização do direito nos casos analisados nesta investigação está em quatro elementos fundamentais: o uso do instrumento da Ação Civil Pública, o acionamento de um enquadramento legal ambiental, a interação com atores operadores do direito (advogados, promotores, procuradores, juízes etc.) e os mecanismos através dos quais elementos simbólicos dos direitos são acionados.

Os enquadramentos legais (legal frames) podem ser entendidos de diversas maneiras. Benford e Snow (2000) entenderam os direitos civis (civil rights) como um tipo de master frame, um enquadramento amplo que é capaz de agregar muitos outros. 
Pedriana (2006) marcou a diferença entre rights e law, argumentando que a norma jurídica produz em si enquadramentos "superiores". Contudo, alinhado com o desenvolvimento teórico da Contentious Politics Theory, Pedriana, salientou que se trata antes de um processo dinâmico do que estático, que envolve interaçóes, agência e estrutura.

$\mathrm{Na}$ literatura é possível observar estudos que tratam de: processos nos quais movimentos sociais substituem enquadramentos não legais por enquadramentos legais; processos de competição entre enquadramentos legais e não legais dentro de um mesmo movimento; processos de competição entre enquadramentos legais por movimentos sociais opostos; processos em que a competição de enquadramento legais ocorre dentro de um mesmo movimento (Hilson, 2009). Vanhala (2011a) observa, também, nos estudos dos movimentos das pessoas portadoras de deficiências, que o próprio enquadramento construído pelo movimento pode levar ao litígio como uma forma estratégica de ação coletiva.

Nas análises que apresentaremos neste artigo, o que observamos é o uso do enquadramento legal ambiental diretamente por parte de movimentos sociais ou de atores como o Ministério Público. Mas com relevo para o fator dinâmico (Pedriana, 2006; Hilson, 2009), já que, como iremos mostrar, a lei ambiental se altera com o uso. Isto é, no uso, o enquadramento legal pode ser modificado, gerando o efeito de atender estrategicamente a reivindicaçóes mais amplas do que aquelas que a lei pretendia abarcar.

De qualquer forma, a construção de um enquadramento legal também depende de estruturas de oportunidades. $\mathrm{Na}$ discussão em questão, interessam as oportunidades legais e jurídicas, mormente o uso da Ação Civil Pública, ${ }^{8}$ mas também das interaçoóes entre atores do campo do direito, tais como promotores e procuradores do Ministério Público, e movimentos sociais. Interessa, ainda, a dimensão simbólica que está presente na mobilizaçâo do direito.

Conforme argumenta Ellen Ann Andersen (2006), não se pode analisar as estruturas de oportunidades legais de forma estática, sem agência. Isso significa que as estruturas de oportunidades legais só ganham relevância quando acionadas pelos atores. Além disso, mobilizar o direito é mais amplo do que usar a lei instrumentalmente. Primeiro, por- que há uma relação de retroalimentação entre frames legais e culturais, na qual discursos e símbolos de ambos moldam o entendimento do outro (Andersen, 2006, pp. 13-14). Segundo, porque a constituição de um repertório de mobilização do direito envolve a construção de interações de litigância que inter-relacionam diversos atores dos movimentos e aqueles que se estabelecem no campo do direito (advogados, promotores, juízes, defensores, burocratas etc.). Leysi Abrego (2008) defende que, além do papel instrumental da legislação, há uma relação bem mais complexa entre a lei e o social, na qual indivíduos também podem influenciar a forma como a lei é interpretada e aplicada.

Sendo assim, entender as múltiplas motivaçóes e os complexos efeitos na interação entre os movimentos sociais e as instituições jurídicas é o núcleo central da agenda da TML. O litígio é uma dentre as muitas dimensóes estratégicas dos movimentos sociais, e é fundamental entender em que momento ele ganha relevo e quais seus efeitos para as mobilizaçôes. A compreensão dos efeitos em duas vias oferece uma possibilidade de avaliação do uso desses recursos na mudança institucional e na compreensão das dinâmicas mais amplas de ação coletiva. Além disso, pode ajudar a compreender porque instituiçóes de Justiça têm sido tão acionadas atualmente. Esses estudos a partir da TML se estabelecem, por um lado, pela análise dos padróes de demandas judiciais quantificáveis e das trajetórias que levam a ação coletiva aos tribunais e, por outro lado, pela análise em profundidade dos litígios e da interação entre seus atores. De uma forma ou de outra, é relevante para os estudos da mobilização do direito compreender tanto os padrōes de ação, a mobilização das instituiçóes de Justiça e os efeitos sobre seus atores, quanto às consequências objetivas e simbólicas desse tipo de mobilização.

\section{Para uma análise dos efeitos da mobilização do direito}

Seguindo a perspectiva de McCann (2010), as investigaçóes nas ciências sociais têm apontado distintas respostas para o protagonismo dos tribunais. Dentre elas, o autor destaca: a posição privilegiada dos tribunais na solução de problemas de coordenação da 
ação; o surgimento e fortalecimento de estruturas de apoio à defesa de direitos como, por exemplo, grupos de advogados; uma posição de elites buscando a manutenção de seus poderes ou o enfraquecimento de outros poderes e sistemas representativos; a resultante de complexos processos de interação entre Estado e sociedade, alicerçados em contextos históricos e políticos (McCann, 2010, pp. 177-181). O autor defende que a explicação mais promissora é a última, compreendida como a do institucionalismo histórico, a qual ganha em complexidade explicativa, mas esta complexidade também a faz perder no que se refere à possibilidade de estabelecer uma lógica causal clara e definidora do processo. A sugestáo dele para melhorar essa abordagem é incorporar a compreensão dos efeitos gerados nas instituições e nos usuários (em nosso caso, os movimentos sociais ou um grupo social específico) a partir da chamada "política de mobilização do direito" (McCann, 2010, p. 181).

O debate proposto por McCann (2006a) sobre a forma como Tilly analisa a mobilização das leis por parte de movimentos sociais é especialmente pertinente para desenvolver os aspectos teóricos que melhor nos permitem avançar em nossa investigação. A crítica de McCann (2006a) é de que a abordagem tillyana resulta em uma visão restrita das leis enquanto recursos e estratégias que são empregados por movimentos sociais na busca de determinados resultados. Nesse sentido, a análise do "sucesso" da ação coletiva via Poder Judiciário ficaria restrita às decisóes judiciais. Diferentemente, o autor propóe que existe uma dimensão simbólica a qual extrapola o caráter estratégico instrumental das ações judiciais (McCann, 2006a, p. 34).

Quanto a isso, os efeitos do uso da lei podem ser compreendidos como "legacy phase", um tipo de impacto da mobilização legal que não pode ser medido meramente através do ganho da causa, mas, especialmente, por um complexo e contextual conjunto de aspectos que são afetados no processo de mobilização (McCann, 2006a, p. 34). Esses aspectos podem estar relacionados à própria mobilização social ou mesmo às mudanças sociais mais amplas.

Outro tipo de análise foi realizada em 1991 por Gerald N. Rosenberg (2008), em The hollow hope - can courts bring about social change? Nessa obra, o autor analisou, entre outros casos, o expres- sivo uso do Judiciário por movimentos de proteção ambiental (Rosenberg, 2008). ${ }^{9}$ Ele observou que historicamente os litígios contribuíram para proteção ambiental na existência de algumas condições: quando incentivos ou custos foram criados por atores externos às Cortes; quando as forças do mercado apoiaram as decisóes; quando os funcionários necessários para implementar as decisóes estiveram dispostos a agir e usaram as decisóes como suporte.

$\mathrm{Na}$ década de 1970, ambientalistas estadunidenses argumentavam que o Judiciário poderia ser capaz de evitar desastres ambientais. Além disso, era comum a impaciência em esperar que o Congresso, legisladores ou governos locais produzissem leis ambientais mais rigorosas. Foi nesse contexto que Rosenberg indagou sobre o porquê desse endereçamento ao Judiciário.

Uma explicação estava na expectativa de obter resultado semelhante ao alcançado pelos movimentos por direitos civis no caso Brown vs. Board. ${ }^{10}$ Nesse sentido, a judicialização tinha a expectativa de garantir em nível constitucional certos direitos relativos à saúde ambiental. Além disso, existia uma percepção de que as Cortes seriam mais confiáveis e mais independentes do mercado do que os demais poderes. Naquele contexto, também consideravam os trâmites do Judiciário mais simples e acessíveis do que os do Legislativo e Executivo. Ademais, embora a Constituição dos Estados Unidos nâo incluísse o direito ao meio ambiente limpo, alguns casos de decisōes nessa direção, nas décadas de 1960 e 1970, abriram precedentes para pleitear tal direito. A brecha que serviu de incentivo foi uma decisão determinando que a ausência de mençáo ao meio ambiente no texto constitucional não significava que de fato este não fosse um direito constitucional, já que é um dever da Corte proteger as minorias, correlacionando-se assim, a proteção ambiental a um direito das minorias interessadas em viver em um ambiente saudável ou garanti-lo às próximas gerações. Entretanto, os ambientalistas não tiveram sucesso na produção de uma garantia constitucional ao direito ao ambiente saudável. Foi a partir dessas observaçóes iniciais que o autor passou a indagar sobre a importância das Cortes para promover os objetivos de legislaçóes ambientais. Além disso, também se perguntou sobre o papel 
das Cortes em promover o movimento ambientalista, decretar legislação ambiental, e produzir efetivamente um ambiente saudável (Rosenberg, 2008).

Essa análise de Rosenberg é exemplar da posição dos estudiosos que se debruçaram sobre a busca pelos tribunais apenas da perspectiva direta das decisóes judiciais.

Uma série de autores recentes da TML, como Vanhala (2011b) tem empreendido esforços de pesquisa para compreender como elementos simbólicos produzem efeitos na lei, na mudança social e nos próprios movimentos sociais. Dentre os efeitos investigados, Vanhala buscou diferenciar o que seriam os efeitos reversos e adversos à mobilização legal (o backlash), porém com uma perspectiva diferente dos "realistas legais", tais como Holzmeyer (2009) e Rosenberg (2008), que se restringiram a perceber os efeitos reversos negativos do uso da lei sobre as mobilizaçóes (Vanhala, 2011b, p. 117). Os "realistas legais" desencorajam o uso dos recursos judiciais, sugerindo que, do ponto de vista estratégico, movimentos sociais têm mais sucesso ao se dedicarem a outras formas de ação.

Para Vanhala (Idem, p. 118), o pessimismo decorre de uma abordagem estritamente focada nos resultados judiciais e nos efeitos destes sobre processos eleitorais, ou seja, em suas implicaçóes institucionais. Dessa forma, a autora amplia a abordagem, incluindo os efeitos reversos para dentro dos próprios movimentos sociais (intra-social movement backlash) e sustentando, com base em dados empíricos, que, além das decisóes e do efeito reverso das decisóes, uma série de outros efeitos decorre do processo judicial sobre a dinâmica interna de movimentos sociais. Entre eles estão o avanço ou mudança no conteúdo das lutas e das táticas legais. Além disso, assim como as identidades coletivas produzem novos conteúdos de direitos, os próprios direitos já estabelecidos são elementos formadores de identidades coletivas (Vanhala, 2011b, p. 121). Comenta, ainda, que a mobilizaçáo legal pode também "provocar reação de uma forma transnacional" (Idem, p. 137, tradução da autora).

Adicionalmente, argumentamos que os ganhos estratégicos não ocorrem apenas ao final da causa. No decorrer do processo judicial, as tensóes geradas no confronto podem gerar ganhos estratégicos intermediários à sentença final. Esses ganhos podem ser relativos às decisóes intermediárias processuais que, em geral, não costumam ser consideradas. Tais ganhos podem significar mudanças importantes no uso das leis e criar precedentes relativos ao processo legal. Ademais, o mais importante é que os efeitos de dimensão simbólica podem explicar por que a mobilização do direito tem passado a se constituir, significativamente, em repertório de açáo coletiva, mesmo com a percepção geral de que processos judiciais são lentos e com frequência não geram as decisóes esperadas.

Esse tipo de abordagem é promissor, pois, segundo Koerner (2012), traz um ponto de vista da vida comum e compreende o direito de forma intrínseca às relaçôes e práticas sociais corriqueiras. Segundo o autor, isso permite ao pesquisador

[...] trazer à tona as especificidades dos direitos para os agentes, nos tempos, situaçóes e condição social nas quais eles vivem e atuam. Então, o direito aparece como mutável, mas também constitui vinculaçóes estreitas com os costumes em comum, ou as formas de vida dos agentes (Koerner, 2012, p. 649).

\section{Efeitos institucionais e efeitos de mobilização}

McCann (2010) compreende dois níveis de relevância dos tribunais na mobilização do direito: um é instrumental e estratégico, e outro, mais sutil e simbólico, o qual diz respeito ao poder de autoridade do universo jurídico sobre a vida social e cultural. Mas, conforme argumenta Maciel (2011, p. 100), "as dimensôes normativa e estratégica do direito são analiticamente inseparáveis”. O nível instrumental é estabelecido sobre o uso dos recursos judiciais enquanto estratégias deliberadas de ação. Buscam-se decisões e existe um cálculo sobre as probabilidades, custos financeiros ou desgastes emocionais gerados no processo. Assim,

[...] a suposição é que os tribunais não apenas solucionam pequenas disputas sobre o significado dos direitos, mas também, previnem, incitam, estruturam, deslocam e transformam conflitos por toda a sociedade rotineiramente (Idem, p. 185). 
Estrategicamente, pode ser importante deslocar o conflito de um nível privado para o público. Os tribunais e instituições periféricas são, também, formas de "certificação" das posiçōes assumidas (Tarrow e Tilly, 2006), ou seja, é uma forma de legitimar determinada posição que encontra dificuldade de ser levada em consideração socialmente ou pelas autoridades. Nesse sentido, no caso dos conflitos ambientais, é importante para os sujeitos envolvidos evidenciarem, através do próprio acolhimento da denúncia ou ação judicial, que tal percepção de injustiça é legítima. Esse aspecto gera um efeito importante sobre as mobilizações sociais, fortalece a posição dos reivindicadores, empodera-os e aumenta a autoestima do grupo social envolvido. Aspecto que percebemos ser fundamental em nossas conversas e entrevistas com os atores litigantes.

O caráter estratégico também pode criar novas arenas de confrontação, como negociaçóes paralelas, acordos ou pressão sobre seus atores. Além disso, as decisóes têm efeitos de encorajar ou desestimular causas, publicizar questóes pouco conhecidas, intensificar as estratégias de movimentos sociais, levando-os para as ruas ou para açóes diretas de confronto, repúdio etc. As decisóes consideradas negativas podem encorajar contramobilizaçóes aos movimentos sociais, além de apressarem certas tomadas de decisão de outros atores políticos.

Não obstante, a análise empírica nos sugere que nos aspectos institucionais também ocorrem efeitos não esperados e que estes não se restringem a aspectos negativos conforme os "realistas legais" na descrição de Vanhala (2011a). Ou seja, a análise empírica de vários processos revela que existem ganhos institucionais dos movimentos que não ti- nham sido inicialmente demandados. Esse elemento corrobora a tese de McCann de que a mobilização do direito envolve uma ampla e complexa rede de relaçôes, de forma que não se pode avaliá-la apenas linearmente pelo ganho na causa que a motiva.

No que se refere ao aspecto simbólico da autoridade judicial, teríamos que considerar a interpretação das doutrinas e as margens de possibilidades que permitem usar as leis de uma forma ou de outra, gerando efeitos distintos. Barclay et al. (2011) argumentam que várias pesquisas empíricas já têm evidenciado os aspectos simbólicos da mobilização legal, através dos quais os movimentos divulgam suas posiçóes, conquistam o apoio de certas elites e podem conquistar novos ativistas. Assim, as mobilizaçōes legais precisam ser sempre consideradas de um ponto de vista processual amplo e contextual. O Quadro 1 sistematiza os tipos de efeitos possíveis levantados nas discussóes da literatura.

\section{Efeitos sobre processos de mobilizaçáo social: análise de conflitos ambientais no Rio de Janeiro e no Espírito Santo}

As ACPs ambientais que levantamos nas duas localidades em estudo representam um conjunto de conflitos que, por trajetórias diferentes, se caracterizam por aquilo que chamamos de mobilização do direito. Isso porque parte desses conflitos envolvem pessoas sem acesso regular às instituiçôes, que empreendem coletivamente reivindicaçôes cujos conteúdos desafiam poderes constituídos no Estado ou no mercado - definição básica de ação política confrontadora (Tarrow, 2009, p. 19) (ver Tabela 1). Mas

\section{Quadro 1}

\section{Tipos de Efeitos na Mobilizaçáo do Direito}

\begin{tabular}{ll}
\hline Efeitos sobre a mobilizaçáo & $\begin{array}{l}\text { Mobiliza, desmobiliza, muda o enquadramento, altera as configuraçóes de alianças, } \\
\text { divulga causas, conquista apoiadores. }\end{array}$ \\
\hline Efeitos institucionais & Muda as leis, cria novas leis, altera o uso das leis (reenquadramentos). \\
\hline Efeitos sobre a demanda & Ganha ou perde. \\
\hline Efeitos sociais & Altera comportamentos, interfere no pensamento e ideias sobre questóes comuns. \\
\hline
\end{tabular}

Fonte: Elaboração própria. 
Tabela 1

Dados Agregados das ACPs Levantadas nos Conflitos Ambientais no Estado do Espírito Santo e na Cidade do Rio de Janeiro

\begin{tabular}{llll}
\hline Proponente & $\begin{array}{l}\text { Cidade do Rio de } \\
\text { Janeiro (\%) }\end{array}$ & $\begin{array}{l}\text { Estado do Espírito Santo } \\
(\mathbf{\%})\end{array}$ & Total (\%) \\
\hline Associaçóes civis & 12,7 & 0,9 & 13,6 \\
MPF & 0,1 & 6,9 & 7,0 \\
MP Estadual & 57,9 & 4,2 & 69,3 \\
Órgão Ambiental e de Patrimônio & 0,4 & 0,4 & 0,8 \\
Executivo Municipal/Estadual & 9,8 & 0,3 & 10,1 \\
Empresa Privada & 0,3 & 0 & 0,3 \\
Não encontrado & 5,7 & 0,4 & 6,1 \\
Total de casos & $689(86,9 \%)$ & $104(13,1 \%)$ & $793(100 \%)$ \\
\hline
\end{tabular}

Fonte: Elaboração própria a partir de consulta às açóes judiciais nos Tribunais de Justiça do ES e RJ e Justiça Federal do ES. Os dados são relativos às ACPs em curso em 2012 na cidade do Rio de Janeiro e às ACPs em curso no Espírito Santo, entre 2004 e 2009 no âmbito federal, somando-se àquelas que já haviam sido julgadas na Justiça estadual entre os anos de 2004 a 2009.

também porque a mobilização do direito implica o uso de oportunidades legais, o uso de um enquadramento legal e de injustiça, bem como as interaçóes que envolvem atores do campo jurídico, conforme o debate teórico apresentado anteriormente.

No que se refere às oportunidades legais, um exemplo é o uso do próprio instrumento da ACP por seus reclamantes ou em interação com elites influentes, tais como promotores, procuradores e defensores públicos.

Todavia, o exame qualitativo de alguns desses conflitos revelou aspectos distintos de constituição da mobilização do direito, o que nos possibilitou compreender como as estratégias judiciais afetam a própria ação coletiva confrontadora.

Conforme argumentamos antes, a mobilização do direito implica a formação de um enquadramento de injustiça (Losekann, 2013). Isso porque, para a mobilização ser enquadrada legalmente, é necessária também a elaboração de uma noção de injustiça. Nesse sentido, observamos empiricamente duas distintas formas de elaboração de injustiças que dialogam com os argumentos teóricos apresentados sobre efeitos.

Em um conjunto desses conflitos, representados nas ACPs em que os movimentos sociais, as- sociações e redes são atores centrais, verifica-se que a noção de injustiça é elemento fundamental para a escolha de uma estratégia judicial. A própria elaboração da petição é parte importante na construção do sentido de injustiça, estabelecendo quem são os aliados, acusados, elaborando a explicação do dano ambiental e da ilegalidade cometida, o que foi percebido na leitura dos processos e nas observaçôes de momentos de interação entre os atores. Nesse conjunto, já há, antes do próprio acionamento da esfera judicial, um enquadramento de injustiça e uma consciência da ilegalidade que direciona o conflito a um enquadramento legal ambiental. Essas ações são em geral movidas por associaçóes, ONGs e, em alguns casos, pela Defensoria Pública e pelo Ministério Público.

Para um segundo conjunto de conflitos, principalmente os que envolvem, em maior número, o Ministério Público, a Defensoria Pública e grupos sociais não anteriormente mobilizados (ou não mobilizados em torno da questão ambiental), é o próprio processo judicial - canalizado via promotores, procuradores e defensores e advogados populares que cria o enquadramento de injustiça ambiental. ${ }^{11}$ Estamos nos referindo, principalmente, a diversas 
populaçóes marginalizadas (pescadores, moradores de regióes impactadas por indústrias etc.). Aqui é fundamental a interpretação de um ator intermediário, que percebe e afirma que dada situação pode ser caracterizada como uma ilegalidade, enquadrada ambientalmente, e, em geral, produzida pela omissão do próprio Estado e pela ação de empresas.

Esse processo, além de criar um canal de viabilização do acesso à Justiça, motiva as pessoas a se engajarem em mobilizaçóes sociais por justiça ambiental. Igualmente, Scheingold (1974) afirma que grupos marginalizados podem, através de processos legais, criar uma conscientização por direitos. Mas é importante frisar que isso é potencial, não necessário. Processos de mobilização do direito dependem de uma série de fatores, tais como aqueles já citados: as oportunidades e frames legais e a existência de atores intermediários que façam a conexão entre os sujeitos e o campo jurídico. ${ }^{12}$

Processos sociais são, para McAdam, Tarrow e Tilly, sequências e combinaçóes de mecanismos causais. Segundo os autores, um dos mecanismos recorrentes em processos de mobilização é a "certificação", que implica, em linhas gerais, na atuação de uma autoridade que apoia ou atesta a reivindicaçáo do ator político. Nos conflitos ambientais, o mecanismo de certificação é um efeito do processo de mobilização do direito, causado pela interação com atores de instituiçóes judiciais e pelo uso do enquadramento legal ambiental. Esse mecanismo não só certifica certas reivindicaçóes, mas produz um efeito de ambientalização dos conflitos pelo uso do enquadramento legal ambiental. Isso fica evidente quando observamos, além dos dados qualitativos dos casos analisados, os dados quantitativos dos tipos de conflitos das ACPs que levantamos. Uma parte importante dos conflitos está relacionado à proteção de populaçóes marginalizadas em zonas urbanas ou em zonas costeiras. Esse dado é importante, uma vez que significa que a legislação ambiental está produzindo, como efeito, acesso à Justiça de populaçôes marginalizadas socialmente.

Além disso, é possível observar que, no decorrer desses processos, sobretudo quando as decisóes são positivas aos marginalizados, ocorre, como efeito, uma "ambientalização continuada", em que outros conflitos sociais passam a ser canalizados via ACP ambiental. Esse efeito extensivo é observado também nas redes transnacionais de ativismo, onde a notícia do uso de açóes judiciais em um país gera um incentivo para grupos que se encontram em situaçóes semelhantes em outros países. Observa-se, também, a difusão das estratégias legais entre grupos sociais vivendo em situação semelhante de impacto ambiental, como pescadores ou afetados por grandes empresas. Também poderíamos pensar a partir do mecanismo de "difusão" definido por Tilly e Tarrow (2006, p. 215) como "a extensão de uma performance contestadora, questáo, ou enquadramento interpretativo de um lugar para outro". Isso ocorre tendo em vista que não existe uma essência dos problemas ambientais, eles são construídos socialmente, tal como argumenta Hannigan (2009).

Usando o esquema de Hannigan (2009) para nossa análise, os atores de intermediação (promotores, defensores, advogados), no caso dos grupos ainda não mobilizados, fazem o papel de "argumentadores”, ou seja, juntam elementos, argumentos que relacionam as diversas situaçóes de precariedade da população com um significado ambiental e social, pedindo providências aos responsáveis e usando a ACP. Eles acionam um processo de criação do enquadramento ambiental de injustiça através da oportunidade legal disponível.

Esse enquadramento também ocorre quando a lei é mobilizada por grupos organizados. Contudo, alguns aspectos são mais custosos a certos grupos sociais. Conforme nossa observação empírica, o problema é argumentado primeiro localmente, por membros da comunidade, líderes e ativistas que vivenciam os efeitos ambientais indesejados. Os casos são elaborados em narrativas complexas, que iniciam na vida cotidiana até se relacionarem com açóes indesejadas, ilegais ou negligentes do próprio poder público e/ou de empresas privadas. Dois dos nossos casos são ilustrativos: o da Associação dos pescadores e Lavradores da Ilha da Madeira vs. Companhia Siderúrgica do Atlântico - CSA, ${ }^{13}$ os pescadores relacionam a falta de peixes à nova instalação da usina siderúrgica na sua regiáo de pesca (zona oeste do Rio, em Santa Cruz). A população desse local também percebe uma "chuva de prata" (partículas de grafite) que frequentemente sai da usina siderúrgica da CSA e suspeita dos im- 
pactos que ela pode gerar à sua saúde. E, no caso da Federaçáo dos Pescadores do Estado do RJ vs. Petrobrás, ${ }^{14} \mathrm{em}$ que buscam a responsabilização da empresa pela poluição da Baía de Guanabara e também pela diminuiçấo e contaminação dos peixes.

Conforme apresentamos na Tabela 2, na análise das nossas 793 ACPs, verificamos que, em $31,27 \%$ dos casos, há relação direta entre as demandas ambientais em questáo nos litígios e as populaçóes empobrecidas e marginalizadas. ${ }^{15}$ Essa caracterização dos litígios enquanto demandas por justiça ambiental fica explícita pela leitura da descrição dos casos, pela característica dos autores e ainda pelas regiốes da cidade, em geral regiôes industriais, pobres e de risco, onde ocorrem os li- tígios. Além disso, percebe-se que os proponentes das ACPs relacionadas à justiça ambiental são exatamente aqueles apontados como atores relevantes no nosso esquema de explicação anterior. Isto é, dos casos em que está presente o enquadramento de injustiça ambiental, 19,8\% foram propostos pela sociedade civil, e em $75 \%$ dos casos onde há esse enquadramento, o proponente da ACP é o Ministério Público estadual ou federal. ${ }^{16}$

Náo obstante, os dados referentes ao tipo de conflito que apresentamos, se comparados com outros dois levantamentos de açóes judiciais ambientais, um realizado na década de 1990 na cidade do Rio de Janeiro por Fuks (2001) e outro realizado por Maciel (2002) em São Paulo, entre 1990 e

Tabela 2

Relaçáo do Litígio com o Enquadramento de Injustiça Ambiental por Proponente

\begin{tabular}{|c|c|c|c|c|}
\hline \multirow[t]{2}{*}{ Proponente } & \multicolumn{3}{|c|}{ Enquadramento de injustiça ambiental } & \multirow[t]{2}{*}{ Total } \\
\hline & Sim & Náo & Indefinido & \\
\hline \multirow[t]{2}{*}{ Associações civis } & 49 & 2 & 57 & 108 \\
\hline & $19,80 \%$ & $2,10 \%$ & $12,70 \%$ & $13,60 \%$ \\
\hline \multirow[t]{2}{*}{ Empresa privada } & 0 & 0 & 2 & 2 \\
\hline & $0,00 \%$ & $0,00 \%$ & $0,40 \%$ & $0,30 \%$ \\
\hline \multirow[t]{2}{*}{ MP estadual e prefeitura } & 0 & 0 & 6 & 6 \\
\hline & $0,00 \%$ & $0,00 \%$ & $1,30 \%$ & $0,80 \%$ \\
\hline \multirow[t]{2}{*}{ MP estadual } & 180 & 82 & 224 & 486 \\
\hline & $72,60 \%$ & $84,50 \%$ & $50,00 \%$ & $61,30 \%$ \\
\hline \multirow[t]{2}{*}{ Órgão ambiental e de patrimônio } & 2 & 0 & 4 & 6 \\
\hline & $0,80 \%$ & $0,00 \%$ & $0,90 \%$ & $0,80 \%$ \\
\hline \multirow[t]{2}{*}{ Executivo municipal/estadual } & 5 & 13 & 63 & 81 \\
\hline & $2,00 \%$ & $13,40 \%$ & $14,10 \%$ & $10,20 \%$ \\
\hline \multirow[t]{2}{*}{ MPF } & 6 & 0 & 50 & 56 \\
\hline & $2,40 \%$ & $0,00 \%$ & $11,20 \%$ & $7,10 \%$ \\
\hline \multirow[t]{2}{*}{ Não encontrado } & 6 & 0 & 42 & 48 \\
\hline & $2,4 \%$ & 0 & $9,40 \%$ & $6,10 \%$ \\
\hline \multirow[t]{2}{*}{ Total } & 248 & 97 & 448 & 793 \\
\hline & $100,00 \%$ & $100,00 \%$ & $100,00 \%$ & $100,00 \%$ \\
\hline
\end{tabular}

Fonte: Elaboração própria a partir de consulta às açóes judiciais nos Tribunais de Justiça do ES e RJ e Justiça Federal do ES. Os dados são relativos às ACPs em curso em 2012 na cidade do Rio de Janeiro e às ACPs em curso, no Espírito Santo, entre 2004 e 2009 no âmbito federal, somando-se àquelas que já haviam sido julgadas na Justiça estadual entre os anos de 2004 a 2009. 
2001, sugerem que o processo de identificação entre conflitos ambientais judicializados e populaçóes marginalizadas é novo. Nos dois estudos, os principais tipos de conflitos giram em torno de danos aos bens naturais ou culturais ou questóes relacionadas aos conflitos de convivência. Nos litígios analisados por Fuks (2001, p. 89), a maior parte estava relacionada à poluiçáo sonora na capital, 24,81\%. O tipo de conflito somado ao fator espacial dos litígios levou o autor a observar que

[...] à medida que nos afastamos da Zona Sul e da classe média/alta organizada desta área do Rio de Janeiro, percebemos uma decrescente mobilização social em torno da defesa do meio ambiente (Fuks, 2001, p. 91)

Nossos dados apontam, então, para uma mudança nos efeitos e também nos usos da mobilização do direito na área ambiental recentemente (ver Tabela 3). Há ainda uma intensificação dos antagonismos com o poder público.

Isso se explica em parte pela argumentação de Acselrad (2010), que descreve a década de 1980 como momento em que a relação entre justiça e meio ambiente ganha relevo no Brasil. A partir daí, mas sobretudo com a Eco92, há uma visível movimentação no sentido de estabelecer conexóes entre ambientalismo e outros temas, tais como indígenas, sem-terra, atingidos por barragens, moradores de periferias, extrativistas e outros. O grupo que o autor nomeia de "ecologismo combativo" é aquele caracterizado por organizaçóes e movimentos sociais estruturados que "ambientalizam as pautas dos grupos subalternos" (Acselrad, 2010, p. 106). Para esse grupo e para outros, a partir dos anos 2000, a noção de "justiça ambiental" torna-se mais presente no país, promovendo certo deslocamento de sentido no ambientalismo, onde as questóes ambientais são pensadas enquanto questóes de Justiça. Esse deslocamento de sentido é especialmente importante para compreendermos como o enquadramento de "injustiça" pode alterar as percepçóes acerca das lutas e conflitos ambientais vividos. Essa noção, além de ampliar os atores e as situações compreendidas enquanto ambientais, politiza as demandas e aponta para mecanismos menos consensuais de desenvolvimento do conflito, criando um caminho para a adoção de um frame legal, tal como descreveu Hilson (2009).

De maneira convergente, quando Lopes (2006) criou e fundamentou a noção de "ambientalização" dos conflitos, também compreendeu que um dos vários elementos que contribuem para esse processo é a institucionalização da importância da preservação do meio ambiente (Lopes, 2006, p. 36), do qual fazem parte as possibilidades de oportunidades e enquadramentos legais. Segundo o autor, a categoria "direitos difusos" contribuiu, na época, para a ampliação da aplicação da lei ambiental. Assim, aspectos como "qualidade de vida", incluindo as futuras gerações, abriram a possibilidade de interpretação, criando novos usos para a lei ambiental.

Dessa forma, as leis contribuem na elaboração das injustiças, servem como fonte de legitimidade para determinadas demandas sociais e, ainda, como mecanismos para identificação de aliados e opositores no terreno amplo da sociedade, mas também na relação com o Estado. Além disso, através das mudanças no uso da lei ambiental, é possível perceber uma complexificação das relaçóes entre sociedade e Estado, onde os primeiros percebem a heterogeneidade dos segundos e a utilizam de forma estratégica.

Mas é importante frisar que nem todo efeito é positivo para os movimentos sociais. O uso estratégico da lei se dá por iniciativa de vários atores, assim, o uso de táticas judiciais ocorre tanto a favor como contra os movimentos. Além disso, existem efeitos adversos e indesejados. O uso estratégico do enquadramento legal ambiental pode primeiramente gerar uma decisão favorável, mas, com isso, acarretar fortalecimento das regulaçôes ambientais e, em certos contextos, pode gerar efeitos contra o próprio grupo social que o usou. Isso é muito comum nos conflitos ambientais contra grandes empreendimentos poluidores e onde existem pequenas comunidades usuárias de recursos naturais. É recorrente a observação do uso estratégico de leis ambientais para barrar ou limitar o empreendimento e, posteriormente, essas mesmas leis serem usadas para limitar as atividades da comunidade, configurando-se em um backlash negativo.

Ou seja, tal qual McCann (2006a, p. 35) afirma, as táticas de mobilização legal não trazem por 
Tabela 3

Tipo de Conflito e Enquadramento de Injustiça Ambiental

\begin{tabular}{|c|c|c|c|c|}
\hline \multirow[t]{2}{*}{ Tipo de Conflito } & \multicolumn{3}{|c|}{ Enquadramento de Injustiça Ambiental } & \multirow[t]{2}{*}{ Total } \\
\hline & Sim & Náo & Indefinido & \\
\hline \multirow[t]{2}{*}{ Mineração } & 3 & 0 & 44 & 47 \\
\hline & $1,20 \%$ & $0,00 \%$ & $9,80 \%$ & $5,90 \%$ \\
\hline \multirow[t]{2}{*}{ Desmatamentos } & 2 & 0 & 9 & 11 \\
\hline & $0,80 \%$ & $0,00 \%$ & $2,00 \%$ & $1,40 \%$ \\
\hline \multirow[t]{2}{*}{ Grandes empreendimentos } & 11 & 0 & 0 & 11 \\
\hline & $4,40 \%$ & $0,00 \%$ & $0,00 \%$ & $1,40 \%$ \\
\hline \multirow[t]{2}{*}{ Importação de pneus, lixo etc. } & 0 & 0 & 2 & 2 \\
\hline & $0,00 \%$ & $0,00 \%$ & $0,40 \%$ & $0,30 \%$ \\
\hline \multirow[t]{2}{*}{ Patrimônio histórico e cultural } & 0 & 0 & 67 & 67 \\
\hline & $0,00 \%$ & $0,00 \%$ & $15,00 \%$ & $8,40 \%$ \\
\hline \multirow[t]{2}{*}{ Obras públicas irregulares } & 4 & 0 & 17 & 21 \\
\hline & $1,60 \%$ & $0,00 \%$ & $3,80 \%$ & $2,60 \%$ \\
\hline \multirow{2}{*}{$\begin{array}{l}\text { Conflitos territoriais (ocupaçáo e construçáo irregular, } \\
\text { favelizaçáo, aterro, parcelamento) }\end{array}$} & 9 & 11 & 167 & 187 \\
\hline & $3,60 \%$ & $11,30 \%$ & $37,30 \%$ & $23,60 \%$ \\
\hline \multirow[t]{2}{*}{ Deslizamento/Situação de risco à população } & 140 & 0 & 0 & 140 \\
\hline & $56,50 \%$ & $0,00 \%$ & $0,00 \%$ & $17,70 \%$ \\
\hline \multirow[t]{2}{*}{ Radiação celular } & 3 & 2 & 1 & 6 \\
\hline & $1,20 \%$ & $2,10 \%$ & $0,20 \%$ & $0,80 \%$ \\
\hline \multirow[t]{2}{*}{ Pesca } & 6 & 0 & 0 & 6 \\
\hline & $2,40 \%$ & $0,00 \%$ & $0,00 \%$ & $0,80 \%$ \\
\hline \multirow[t]{2}{*}{ Participação/Empoderamento da sociedade civil } & 2 & 0 & 0 & 2 \\
\hline & $0,80 \%$ & $0,00 \%$ & $0,00 \%$ & $0,30 \%$ \\
\hline \multirow[t]{2}{*}{ Prejuízo por enchentes } & 1 & 0 & 0 & 1 \\
\hline & $0,40 \%$ & $0,00 \%$ & $0,00 \%$ & $0,10 \%$ \\
\hline \multirow{2}{*}{ Poluição do ar, da água e produtos químicos } & 51 & 3 & 27 & 81 \\
\hline & $20,60 \%$ & $3,10 \%$ & $6,00 \%$ & $10,20 \%$ \\
\hline \multirow[t]{2}{*}{ Poluição sonora } & 0 & 64 & 0 & 64 \\
\hline & $0,00 \%$ & $66,00 \%$ & $0,00 \%$ & $8,10 \%$ \\
\hline \multirow[t]{2}{*}{ Lixo } & 11 & 0 & 8 & 19 \\
\hline & $4,40 \%$ & $0,00 \%$ & $1,80 \%$ & $2,40 \%$ \\
\hline \multirow[t]{2}{*}{ Outros } & 5 & 17 & 19 & 41 \\
\hline & $2,00 \%$ & $17,50 \%$ & $4,20 \%$ & $5,10 \%$ \\
\hline \multirow[t]{2}{*}{ Não identificado } & 0 & 0 & 87 & 87 \\
\hline & $0,00 \%$ & $0,00 \%$ & $19,40 \%$ & $11,00 \%$ \\
\hline \multirow[t]{2}{*}{ Total } & 248 & 97 & 448 & 793 \\
\hline & $100,00 \%$ & $100,00 \%$ & $100,00 \%$ & $100,00 \%$ \\
\hline
\end{tabular}

Fonte: Elaboração própria a partir de consulta às açôes judiciais nos Tribunais de Justiça do ES e RJ e Justiça Federal do ES. Os dados são relativos às ACPs em curso em 2012 na cidade do Rio de Janeiro e às ACPs em curso, no Espírito Santo, entre 2004 e 2009 no âmbito federal, somando-se àquelas que já haviam sido julgadas na Justiça estadual entre os anos de 2004 a 2009. 
si só, necessariamente, benefícios aos cidadãos desempoderados. $\mathrm{O}$ uso das leis importa, mas os resultados dependem dos contextos.

\section{Efeitos sobre as instituiçóes: Campanha por um Brasil Livre de Transgênicos}

Para desenvolver nosso argumento dos efeitos que o litígio estratégico pode gerar sobre as instituiçôes, apresentaremos o caso da estratégia de litigância da Campanha por um Brasil Livre de Transgênicos, cujas ações foram analisadas em profundidade em nossas pesquisas, permitindo-nos identificar e compreender efeitos que alteram padróes institucionais, criando inovaçóes nas leis e novos instrumentos de controle das instituições.

Analisamos quatro ACPs como parte de um processo de mobilização que gerou a determinação de regras para a aprovação dos Organismos Geneticamente Modificados (OGM) pela CTNBio (Comissão Técnica Nacional de Biotecnologia) e a lei que determina a rotulagem dos produtos comercializados que contêm OGM. Nesse sentido, discutimos como a mobilizaçáo do direito também pode contribuir para gerar processos de redesenho incremental das instituiçôes.

$\mathrm{O}$ processo que caracteriza os efeitos de mudanças institucionais envolveu também o uso de oportunidades legais, a utilização de enquadramentos legais e o apoio de atores estratégicos, sobretudo o Ministério Público Federal, que encampou a campanha contra os transgênicos criando, em 2007, um Grupo de Trabalho (GT) específico sobre "agrotóxicos e transgênicos". ${ }^{17}$

\section{Inovando as normas: o caso da rotulagem dos transgênicos}

A Campanha por um Brasil Livre de Transgênicos (CBLT) surgiu em 1998 junto com a primeira $\mathrm{ACP}$ que marca o início das estratégias litigantes contra os transgênicos no país. A campanha, inicialmente composta por Idec, Greenpeace Brasil, Assessoria e Serviços a Projetos em Agricultura Alternativa (AS-PTA), ActionAid Brasil, Instituto de Estudos Socioeconômicos (Inesc), FASE
| Solidariedade e Educação e Centro de Pesquisa e Assessoria (Esplar), apresentou quatro tipos estratégicos de ação: jurídica, mediante o uso de oportunidades legais; parlamentar, via uma ação de monitoramento e pressão semelhante ao lobby; açôes no Executivo federal, também por meio de monitoramento e pressão dos conselhos, agências de controle e ministérios; e açóes na mídia, basicamente, produzindo e difundindo informaçáo sobre o tema (Relatório, 2002). ${ }^{18}$

A luta contra os transgênicos é um fenômeno mundial e em vários países ocorrem campanhas com características muito similares. Além disso, apesar da ênfase institucional dada no relatório explicando o surgimento da CBLT, as ONGs envolvidas são em grande parte conhecedoras e desenvolvedoras de performances inovadoras de contestação. Na CBLT, não foi diferente. Da confecção de guias de compras de produtos sem transgênicos, passando pelo etiquetamento desobediente de ovos de Páscoa com o “T” dos transgênicos, e chegando a elaboração de imagens ${ }^{19}$ com o objetivo de "choque moral" (Jasper, 1997), foram criativas e amplas as performances produzidas na CBLT. Além disso, a formação de uma rede diversificada de atores, que incluiu, desde o início, organizaçóes de apoio aos agricultores, como a AS-PTA, até grandes ONGs internacionais, permitiu a manutenção de trabalhos de incentivo à produção de sementes não transgênicas junto aos produtores rurais.

A CBLT evidencia como o uso de estratégias legais fazem parte de um amplo repertório, como protestos, lobby legislativo, produção de informação e formação de alianças. Mas, desde o início, a campanha constituiu um repertório francamente judicial e um enquadramento legal que transitava entre os direitos do consumidor e questóes ambientais. Com o tempo, o terceiro elemento característico das mobilizaçóes analisadas anteriormente também se fez presente, qual seja, a aliança estratégica com um ator importante, o Ministério Público Federal. Este que acabou encampando as lutas e criando um grupo de trabalho dentro de sua própria estrutura, ligado à $4^{\circ}$ Câmara de Meio Ambiente e Patrimônio Cultural - o que por si só já significa uma influência das reivindicaçóes de movimentos sociais sobre atores e instituiçōes estatais. 
O litígio pela rotulagem dos transgênicos começa em 1998, no contexto inaugural da CBLT, com a abertura de uma primeira ACP pelo Idec e Greenpeace ${ }^{20}$ e tem um segundo momento em 2001, com a abertura de uma nova ação. ${ }^{21}$ A primeira é uma ação emblemática porque representa os primeiros momentos de conflitos judiciais envolvendo os transgênicos no país, aberta pouco depois da entrada ilegal de soja geneticamente modificada no Brasil.

Na primeira ACP de 1998, o Idec apontou inúmeros problemas na liberação da soja $\mathrm{RR}$, e, baseando-se no Código de Defesa do Consumidor (CDC), a organização reclamou, entre outras coisas, por uma rotulagem que identificasse ao consumidor se o produto continha ou não OGM. Essa ação gerou inúmeros desdobramentos e decisões diferentes quanto a essas e outras questôes. No entanto, para o que pretendemos discutir neste artigo, damos relevo à luta pela rotulagem.

Uma primeira decisão ocorreu em 2000, favorável à rotulagem e que deu origem ao primeiro decreto que regulamentou a questão. Diante de todas as problemáticas - ambiental, saúde e consumidor -, a Uniāo concordou em maior medida com a necessidade de normas técnicas para atender ao direito do consumidor à informação adequada, em acordo com CDC. Nesse sentido, o enquadramento legal inicial foi o do direito do consumidor e podemos vislumbrar um primeiro efeito institucional, já que o litígio gerou a formulação de uma norma antes não existente. Trecho da decisão:

[...] o consumidor tem o direito básico a informação adequada e clara, com especificação correta de características, composição, qualidade, riscos que apresentem, entre outros dados [...]. Este aspecto da demanda judicial é reconhecido inclusive pela RÉ União Federal que já determinou [...] a criação de uma Comissão Interministerial com o fim de elaborar norma sobre rotulagem de transgênicos, conforme Portaria no 268/90 do Departamento de Proteção e Defesa do Consumidor/Ministério da Justiça, estando em discussão a proposta oficial (Brasil, TRF 1, AC 1998.34.00.027682-0, 26 de junho de 2000, p. 48).
Da Comissão Interministerial, formada durante o governo FHC para deliberar sobre o tema, saiu o Decreto no 3.871/2001. Nesse primeiro decreto, a exigência era de que o rótulo fosse obrigatório caso a presença de OGM ficasse acima de 4\%. Para o Idec, esta medida foi insuficiente e, junto com MPF, o instituto abriu uma nova ACP, a de 2001, impetrada contra a União Federal. Essa ação traz uma nova insatisfação quanto à forma como as informaçôes sobre os transgênicos é exposta nas embalagens: para eles, o CDC e o art. $5^{\circ} \mathrm{da}$ Constituição Federal preveem que tais dados devem ser claros para o consumidor e a rotulagem deve ocorrer em qualquer quantidade, e não somente acima de 4\%, como previa o decreto de 2001.

Há, também, neste litígio, a exigência de que a fiscalização dos produtos que contêm OGM seja efetiva. Para os autores do processo, a União Federal era ausente na cobrança da rotulagem, seja de alimentos industriais, seja de alimentos in natura. Além disso, diante da irregularidade, os produtos deveriam ser retirados de comercialização.

Essa pressão pela elaboração de normas mais rigorosas deu origem ao Decreto n. 4.680/2003, assinado em abril daquele ano pelo então Presidente Lula antes mesmo de qualquer decisão judicial, no qual a rotulagem não só se tornou obrigatória com uma presença de OGM mínima, que caiu de $4 \%$ para $1 \%$, como também passou a ser exigida em produtos embalados, vendidos a granel, in natura $\mathrm{e}$ mesmo em animais para consumo humano alimentados com transgênicos. Outro aspecto relevante é a presença da espécie doadora do gene no local de identificação dos ingredientes.

Em dezembro de 2003 foi criada a Portaria n. 2.658/2003 para determinar o símbolo e as informaçóes obrigatórias no rótulo: o tamanho do símbolo deve ser $0,4 \%$ da embalagem, respeitado o tamanho mínimo de $5 \mathrm{~mm}$; deve conter informaçóes sobre o produto próximo ao triângulo equilátero com " $T$ " maiúsculo no centro; em embalagens policromáticas, as bordas e letras são pretas, o interior do triângulo é amarelo.

Nota-se, portanto, que, antes mesmo da primeira decisão sobre a segunda ação no conflito Idec vs. União Federal, o governo adotou parâmetros normativos mais rigorosos diante da permanência do 
conflito em pleitos. Contudo, essa redução de 4\% para $1 \%$ não satisfez plenamente a entidade. Uma advogada do Idec nos fala sobre os embates:

[...] com base no Código, nós levamos essa bandeira para ter uma norma de rotulagem. Isso levou anos, entâo brigamos no judiciário para ter isso, e depois, junto ao Ministério da Justiça, para conseguir uma norma que regulamentasse e que detalhasse esse direito que já estava garantido pelo Código de Defesa do Consumidor. Então foi uma grande batalha e daí saiu uma norma, tínhamos na Justiça ação questionando para ter essa norma, e questionamos que a norma não poderia sofrer nenhum limite (Advogada do Idec, entrevistada em 2013).

Essa ACP de 2001 teve dois julgamentos favoráveis à informação sobre transgênicos estar sempre presente: o primeiro em 2007, na Justiça Federal; o segundo, em 2012, após apelação ao Tribunal Federal da 1a Região. Entretanto, ao final de 2012, o julgamento no Supremo Tribunal Federal (STF) reverteu essa decisão e a norma vigente permanece sendo o decreto de 2003.

A partir do exposto, concluímos que o litígio Idec e Greenpeace vs. Monsanto e União Federal, que funda a CBLT, deu início a um repertório de mobilização do direito que foi determinante no ganho institucional da rotulagem dos transgênicos, ainda que não tenha atendido estritamente o desejado pela organização. Além disso, tem grande relevância os pedidos de cobrança da fiscalização e efetividade da lei. A reação do polo favorável à transgenia continuou com investidas diretas, como a elaboração de projetos de lei que visam alterar a norma. ${ }^{22}$

\section{Criando mecanismos de controle: o monitoramento dos transgênicos}

Apesar dos ganhos com a rotulagem, diversas outras iniciativas foram propostas pelos defensores da transgenia, e, em 2005, com a aprovação da Lei de Biossegurança (Lei n. 11.105/2005), a CTNBio (Comissão Técnica Nacional de Biossegurança) passou a ter a competência exclusiva para deliberar sobre matéria de aprovação dos OGMs. Essa auto- nomia é um dos pontos mais criticados pelos setores contra os transgênicos. Um papel fundamental da AS-PTA e da Terra de Direitos ${ }^{23}$ nesse processo é que ambas acompanham rotineiramente a atividade da CTNBio. Isso graças a um Mandado de Segurança que assegura que as sessóes da Comissóes sejam abertas ao público. ${ }^{24}$

Em 2007, diante de um diagnóstico de irregularidade técnica ligada à liberação de milho transgênico Liberty Link, da Bayer, foi aberta na Justiça Federal do Paraná uma ACP de autoria da AS-PTA, do Idec, da Terra de Direitos e da Associação Nacional do Pequenos Agricultores (ANPA) vs. CTNBio, Monsanto, Bayer e Syngenta. ${ }^{25}$ Nessa, a Comissão era acusada de delegar o plano de monitoramento dos cultivos à empresa que pediu a liberação. As autoras buscaram fundamentação legal no próprio art. 14 da Lei de Biossegurança que, dentre outras coisas, diz que a comissão deve estabelecer critérios de avaliação e monitoramento de riscos, reavaliar suas próprias decisóes caso solicitado por órgãos e entidades de registro e fiscalização - o que não havia feito até então.

O que se percebe nesse segundo recorte é uma estratégia litigiosa que surge de oportunidades, mas, também, de restriçóes legais e políticas (a proibição inicial das organizaçóes da sociedade civil de participarem nas reuniôes da CTNBio). Além disso, observa-se que o mesmo frame legal contra o qual as organizaçóes litigaram anteriormente, agora é estrategicamente mobilizado (art. 14 da lei de biossegurança). Isso revela as idas e vindas que envolvem todo o processo de disputa em torno da causa, explicitando a dimensão dinâmica da mobilização do direito tal como Pedriana sugeriu (2006). Assim, conforme os argumentos de Andersen (2006) e Vanhala (2011a), apresentados no início, oportunidades e restriçóes precisam ser percebidas, e mais, podem ser criadas no próprio processo de mobilização tendo em vista os efeitos da própria agência sobre as estruturas.

Deste tensionamento, uma decisão liminar, ainda em 2007, exigiu a elaboração de um plano de monitoramento pós-liberação comercial da espécie transgênica e a obrigatoriedade de medidas de biossegurança para evitar a contaminação, via polinização, de cultivos de milho não transgênicos. Para cumprir 
com as demandas da Justiça, a CTNBio teve que elaborar normas de monitoramento. Exemplo disso é a Resoluçấo Normativa (RN) n. 4. Esta substituiu a $\mathrm{RN}$ n. 3, que delegava às empresas a apresentação de um plano de monitoramento do OGM.

Contudo, as organizaçóes, ainda insatisfeitas com a RN n. $4^{26}$, iniciaram uma nova etapa litigiosa pedindo a anulaçáo da liberação dessa espécie de milho transgênico e a exigência da elaboração de normas mais rígidas. Após diversos andamentos e decisóes desfavoráveis, em um terceiro julgamento, em 2014, em decisão emblemática proibiu-se o plantio do milho Liberty Link no Norte e no Nordeste do país. Tal proibição foi, na época, noticiada em diversas mídias e nas redes sociais, justamente por reverter uma aprovação da CTNBio. A decisão é até hoje citada como exemplo de êxito da mobilização contra os transgênicos.

Diante do exposto, podemos dizer que os objetivos do litígio iniciado em 2007 foram parcialmente alcançados. $\mathrm{O}$ voto final nesses litígios foi por prover parcialmente o pedido das autoras: atendeu o objetivo de exigir a elaboração de normas de biossegurança, demandou mais transparência nos processos e até mesmo proibiu o cultivo de milho transgênico; porém, não considerou substancialmente a avaliação técnica das organizaçóes, que traz elementos em prol de normas, na avaliação delas, ainda mais eficazes. As palavras do entrevistado revelam a percepção sobre os ganhos e perdas nesse caso:

Tem coisas que ela faz (CTNBio), e só faz a partir de interpelaçóes que fizemos na Justiça. Para dar um exemplo, naquela primeira liberação do milho transgênico da Liberty Link, da Bayer, a CTNBio não tinha sequer um protocolo interno de como avaliar um pedido de liberação comercial. [...] Nós questionamos isso e o Judiciário entendeu que era necessário um protocolo para avaliar os pedidos e hoje em dia eles têm que desenvolver isso. Se é bom ou não é uma outra história... A mesma coisa para regras de isolamento. Como evitar, ou tentar evitar que um plantio de transgênicos não contamine o vizinho que é orgânico ou é agroecológico. Também não existia isso! Depois da liberação, o Judiciário entendeu que precisa ter.
Foi criada essa regra. [...] Uma outra questáo que conseguimos por meio da Justiça foi que a CTNBio, ao aprovar o plantio comercial de qualquer produto, tenha que demandar da empresa um plano de monitoramento pós-comercialização. São alguns exemplos de conquistas obtidas por decisão judicial e contribuem para garantir uma legislação mais rigorosa (Técnico da AS-PTA, entrevistado em 2013).

Por fim, concluímos que, do ponto de vista de incrementos institucionais, vários ganhos podem ser apontados a partir dos casos de confronto aos transgênicos (ver Quadro 2).

Não é simples avaliar o sucesso da mobilização do direito no caso dos transgênicos. Isso porque, embora não se tenha efetivamente barrado o desenvolvimento dos transgênicos e reiterado nessa e em outras açóes judiciais a autoridade exclusiva da CTNBio, ${ }^{27}$ muitas regras que limitam e controlam a sua exploração só existem em função dessa mobilização. As mudanças observadas não são desprezíveis. É por isso que a avaliaçáo dos atores sobre o resultado da entrada do Judiciário na arena de debates dos transgênicos é positiva.

[...] entendemos que, ganhando ou não, estamos cumprindo um papel que é o de levar o tema dos transgênicos e todos os impactos que ele causa para o Judiciário. Eventualmente perdemos açōes, temos negados pedidos feitos ou algum precedente que acaba virando contra o que buscamos, mas, avaliamos que, a partir de nossas açóes, nós forçamos a Justiça a tratar do assunto. Eles tiveram que estudar, que buscar outras decisóes semelhantes de outros países, estudar a legislação, de certa forma apurar que existe um debate técnico nessas açóes e há, ainda, muitas divergências no campo científico. [...] Então, os temas são novos para o Judiciário e entendemos que estamos contribuindo para que os assuntos sejam discutidos lá dentro. Estamos quebrando tabus e iniciando o debate de temas até então desconhecidos da Justiça (Técnico da AS-PTA, entrevistado em 2013). 


\section{Quadro 2}

\section{Mudanças Institucionais}

Decreto no 4680/2003 - Regulamenta o direito à informaçáo sobre alimentos que contenham ou sejam produzidos a partir de OGMs.

Criação da regulamentação dos procedimentos internos para a tramitação de processos de requerimento de aprovação de OGMs na CTNBio

Portaria no $^{\circ} 373$, de $1^{\circ}$ de junho de 2011 -MCT

Altera o Regimento Interno da Comissáo Técnica Nacional de Biossegurança - CTNBio.

Criação de regra para garantir que a plantação do transgênico não contamine o plantio agroecológico/orgânico e regra de monitoramento após as liberaçóes e plantio.

Ex.: Resoluçáo Normativa no 4 e no 5 da CTNBio

Fonte: Elaboração própria a partir dos dados das ACPs citadas e das entrevistas realizadas.

O fator "tempo" precisa ser levado em consideração na análise de efeitos. Mudanças institucionais são frequentemente de médio e longo prazos, enquanto efeitos sobre processos de mobilização ou processos políticos podem ser de curto prazo. Já efeitos em termos de mudanças sociais podem exigir muitas geraçôes de estudiosos para serem verificadas.

Em síntese, diversas inovações institucionais vêm sendo produzidas com origem nas demandas de movimentos sociais, através do litígio estratégico. Mas, mesmo enfatizando os aspectos institucionais, é preciso salientar que a percepção de ganhos através de determinada ferramenta estratégica gera efeitos também sobre a mobilização. Nesse sentido, temos um processo que incentiva o surgimento de um repertório específico, a mobilização do direito.

Embora os atores usem estrategicamente as ferramentas do direito, eles não têm controle absoluto sobre os efeitos. Logo, concordamos com McCann (2006b), o qual observa que atores criam interpretaçōes post hoc sobre os efeitos de suas açóes e são essas percepções posteriores (avaliaçóes) que fundamentam novas investidas ou não no terreno do direito. Foi isso que aconteceu de certa forma com os atores protagonistas da CBLT, avaliando e direcionando seus esforços para a construção de repertórios mais profícuos na medida em que observaram seus efeitos sobre as instituiçóes.

\section{Consideraçóes finais}

Enfrentar a discussão sobre os efeitos da litigância que parte de, ou envolve, movimentos sociais exige muito mais do que uma observação linear entre causa e efeito. Exige matizar os diferentes tipos de efeitos. O litígio é uma das formas estratégicas presentes em processos de ação coletiva e não pode ser compreendido apenas no sentido jurídico, ainda que esta seja uma dimensão específica a ser considerada na mobilização do direito. O que propomos foi observar outros aspectos, pouco analisados, aproximando achados empíricos das discussóes da Legal Mobilization Theory. Certamente existem ainda outros efeitos que somente novas investidas investigativas poderão evidenciar.

As análises dos casos estudados nos mostram que esse conjunto complexo de efeitos gerados pela mobilização do direito pode nos ajudar a explicar porque instituições de Justiça têm sido tão acionadas atualmente. Pudemos observar mudanças e incrementos institucionais provocados por litígios estratégicos e percebidos pelos atores. Além disso, observamos uma gama de interaçóes entre operadores do direito e demandantes que criam sentidos, reforçam ou originam processos mobilizadores.

As especificidades dos casos analisados mostram diferenças importantes nas interaçôes que envolvem instituições judiciais. Nos casos envolvendo conflitos 
ambientais caracterizados por injustiças ambientais atingindo populaçóes locais e marginalizadas, os efeitos observados incidem sobretudo nos próprios processos de mobilização social. Já o caso da Campanha por um Brasil Livre de Transgênicos evidencia claramente o quanto grandes organizaçóes, com muitos recursos de mobilização, canalizaram suas estratégias para as instituiçôes judiciais, garantindo por essa via a introdução de uma perspectiva crítica ao tema dos transgênicos na agenda política.

Os elementos simbólicos e institucionais analisados nos indicam que as leis e as instituiçóes de Justiça são arenas importantes para a realização dos confrontos nas democracias contemporâneas. A análise dos efeitos, em duplo sentido (sobre movimentos e sobre instituições) é uma agenda que pode contribuir para o avanço das teorias e da compreensão ampla do nosso mundo.

Assim, as questóes apresentadas neste artigo, longe de encerrarem a discussão, buscaram, a partir dos achados de pesquisa, contribuir para a complexificação e fortalecimento dessa agenda de pesquisa, ainda incipiente no Brasil, em torno das relaçóes entre movimentos sociais e o direito.

\section{Notas}

1 Embora exista já alguma elaboração teórica sobre a noção de litígio estratégico, principalmente no campo do direito (Contreras, 2011; Cardoso, 2011), neste artigo usaremos a expressão simplesmente como forma de especificar o litígio quando este é utilizado de forma estratégica e tática em processos de ação coletiva, sentido desenvolvido por Vanhala (2011a).

2 A expressão legal mobilization tem sido traduzida para o português como "mobilizaçáo do direito". Nesse exercício de tradução, a intenção é usar uma denominação mais ampla, abarcando tanto aspectos institucionais, como as leis, quanto aspectos não institucionais, como as interações entre atores. Trata-se, portanto, não de uma tradução literal, mas de uma adaptação.

3 O acompanhamento das açóes é parte de um projeto de extensão e pesquisa - financiado pelo MEC, edital Proext/2014 - e as açóes são atualizadas a cada três meses por bolsistas dos cursos de Direito e de Ciências Sociais. Mais informaçôes em: <http://organon. ufes.br>.
4 Para os objetivos deste artigo, foram analisados apenas as ACPs.

5 Para os dados quantitativos, construímos um banco de dados das ACPs a partir das informaçóes disponibilizadas pela Procuradoria da República no Espírito Santo e pela $1^{\text {a }}$ Promotoria de Tutela Coletiva de Meio Ambiente e Patrimônio Cultural da Capital (MPRJ). Consultamos, também, as açôes disponíveis no site do Tribunal de Justiça do Espírito Santo e do Tribunal de Justiça do Rio de Janeiro. Para a categorização que apresentamos, consultamos os registros on-line de cada ação judicial registrada nos respectivos tribunais. Dados foram analisados com o auxílio do Statistical Package for Social Science (SPSS) versão 22, QGis 2.8 e GeoDa 1.6.6. (Esta pesquisa foi financiada pelo CNPq.)

6 Esta pesquisa foi realizada inicialmente como bolsa de iniciação científica com o apoio de bolsa do CNPq e, posteriormente, foi continuada em nível de mestrado com apoio de bolsa da Capes.

7 Estes conflitos estão materializados em ação judiciais que fazem parte do nosso banco de dados. Desde 2012, temos acompanhado com bastante proximidade atores e processos de mobilização que envolvem, sobretudo, comunidades afetadas por grandes empreendimentos nas localidades da pesquisa. Além das entrevistas, participamos de eventos de mobilizaçáo e realizamos visitas nas localidades afetadas.

8 No Brasil, a Constituição de 1988 é um marco importante da consolidação tanto dos direitos difusos quanto das formas de controle judicial para a promoção desses direitos. É nesse momento que o Ministério Público ganha autonomia saindo da alçada do Executivo, tornando-se o principal agente na defesa dos direitos coletivos, canalizando conflitos dessa ordem para o âmbito judicial. Além disso, o meio ambiente é o tema inaugural da normatização dos direitos difusos através da Política Nacional de Meio Ambiente de 1981. Destacamos aqui dois novos instrumentos legais: a legitimidade do Ministério Público na proposiçáo de Ação de Responsabilidade Civil e Criminal por danos ao meio ambiente e a Ação Civil Pública que, além do Ministério Público, pode ser promovida pela União, estados e municípios, autarquias, empresas públicas, fundaçóes e sociedades de economia mista e, com destaque para o nosso propósito, associaçóes com mais de um ano de existência e que incluam a proteçáo ao meio ambiente, ao consumidor e/ ou patrimônio histórico e cultural entre suas finalidades.

9 Cabe notar que os litígios ambientais são referidos pelo autor como demandas por um "meio ambiente 
mais limpo e saudável" (cleaner and healthier environment). Mais adiante, apontaremos as diferenças importantes que nossa pesquisa apresenta dos sentidos dos litígios ambientais.

$10 \mathrm{Na}$ decisão do caso Brown vs. Board of Education of Topeka, a Corte Suprema dos Estados Unidos declara inconstitucional a separação entre estudantes negros e brancos nas escolas públicas.

$11 \mathrm{O}$ enquadramento de justiça (ou injustiça) ambiental surgiu nos Estados Unidos nos anos 1980 quando se percebeu que certos grupos sociais sofriam mais impactos ambientais do que outros. A perspectiva da justiça ambiental relaciona, portanto, impactos ambientais e desigualdades sociais. Um trabalho semelhante nesse sentido é o de Capek (1993) sobre a formação de um "environmental justice frame", nos anos 1980, como expansão do "civil rights frame" dos 1960 nos Estados Unidos.

12 A análise detalhada do papel do ator intermediário, que poderia ser resumidamente descrito como broker (Tilly e Tarrow, 2006) não cabe neste artigo e será oportunamente apresentada em trabalhos futuros.

13 ACP n. 2006001059224-6 e ACP n. 00538375520068190001. Existem outras ACPs de outras associaçóes contra a mesma empresa nessa localidade.

14 ACP n. 0481524-29.2012.8.19.0001. A Federação tem várias açốes contra a petroleira Chevron e outras que operam na regiáo da Baia de Guanabara.

15 Chegamos a esse percentual a partir da verificação simples dos dados sobre autores, regiôes e resumos dos conflitos. Em alguns casos, a leitura dessas informaçôes não foi suficiente, ou restou alguma ambiguidade para afirmar com certeza que o litígio se refere a uma injustiça contra grupos empobrecidos e marginalizados; nestes casos, classificamos como "não identificado".

16 Embora alguns trabalhos reconheçam diferenças importantes nas atuaçóes dos MPs em âmbito estadual ou federal, pela natureza dos nossos dados, esse tipo de análise não se torna significativa.

17 Portaria 4a CCR n. 06 de 4 de maio de 2007.

18 Disponível apenas on-line em: <http://www.social. org.br/relatorio2002/relatorio009.htm>. Acesso em: 20 maio 2016.

19 Entre algumas imagens, podemos citar uma foto de maçãs recebendo injeçôes e outra apresentando ratos com deformaçóes.

20 ACP n. 1998.34.00.027682-0. IDEC (Instituto de Defesa do Consumidor) e Greenpeace vs. Monsanto e União Federal.
21 ACP no 2001.34.00.022280-6. Os autores da ACP de 2001 são o Idec e o Ministério Público Federal, e a ré é a União Federal. A Associação Brasileira das Indústrias da Alimentação (ABIA) é litisconsorte passiva.

22 É o caso do Projeto de Lei (PL) n. 4.148/2008, do deputado Luis Carlos Heinze (Partido Progressista - PP/ RS), já aprovado na Câmara dos Deputados este ano, e que, na opinião dos que são contrários aos transgênicos, visa dar fim à rotulagem.

23 A organizaçáo Terra de Direitos encampa a Campanha no início dos anos 2000, segundo informaçáo obtida em entrevista.

24 Mandado de Segurança 2007.34.00.012278-6/DF, de autoria do Ministério Público Federal, garante que as reunióes de votaçấo e das subcomissóes da CTNBio permitam acesso ao público.

25 ACP de n. 2007.70.00.015712-8/PR.

26 A RN n. 4 não tratou da coexistência entre cultivos transgênicos e não transgênicos e estabeleceu uma distância mínima insuficiente para impedir a polinização pelo vento.

27 Apesar de não termos abordados aqui, no próprio caso Idec vs. Uniáo Federal é dada autoridade exclusiva à CTNBio em estudo de impacto ambiental, por exemplo.

\section{BIBLIOGRAFIA}

ABREGO, L. (2008), "Legitimacy, social identity, and the mobilization of law: the effects of Assembly Bill 540 on Undocumented Students in California”. Law \& Social Inquiry, 33 (3): 709-734.

ANDERSEN, E. A. (2006), Out of the closets and into the Courts: legal opportunity structure and gay rights litigation. Ann Arbor, University of Michigan Press.

ACSELRAD, H. (2010), "Ambientalização das lutas sociais: o caso do movimento por justiça ambiental”. Estudos Avançados, 24 (68): 103119.

ACSELRAD, H.; CAMPELLO, C. \& BEZERRA, G. (2009), O que é justiça ambiental. Rio de Janeiro, Garamond.

BARCLAY, S. et al. (2011), "Two spinning wheels: studying law and social movements", in Austin Sarat (ed.), Special issue social movements/legal 
possibilities, Bingley, Emerald Group Publishing (Studies in Law, Politics and Society, 54).

BENFORD, R. \& SNOW, D. (2000), "Framing processes and social movements: an overview and assessment". Annual Review of Sociology, 26: 611-639. Disponível em: <http://www. jstor.org/stable/223459>. Acesso em: 25 jan. 2017.

BLACK, D. J. (1973), "The mobilization of law". The Journal of Legal Studies, 2: 125-149.

BRIGHAM, J. (1990), "Bad attitudes: the consequences of survey research for constitutional practice". The Review of Politics, 52 (4): 582-602.

CAPEK, S. M. (1993), “The 'environmental justice' frame: a conceptual discussion and an application”. Social Problems, New York, 40 (1): 5-24.

CARDOSO, E. (2011), "Ciclo de vida do litígio estratégico no sistema interamericano de direitos humanos: dificuldades e oportunidades para atores não estatais". Revista Electrónica del Instituto de Investigaciones "Ambrosio L. Gioja", 5: 363-378.

COLE, L. W. \& FOSTER, S. R. (2001), From the ground up: environmental racism and the rise of the environmental justice movement. Nova York, NYU Press.

CONTRERAS, J. C. G. (2011), Modelo para armar: litigio estratégico en derechos humanos. México, DF, Comisión Mexicana de Defensa y Promoción de los Derechos Humanos AC.

CRENSHAW, K. W. (1988), "Race, reform, and retrenchment: transformation and legitimation in antidiscrimination law". Harvard Law Review, 101 (7): 1331-1387.

CURRIER, A. (2011), "Decolonizing the law: LGBT organizing in Namibia and South Africa”, in A. Sarat (ed.), Special issue social movements/Legal possibilities, Bingley, Emerald Group Publishing (Studies in Law, Politics and Society, 54).

DELGADO, R. et al. (1985), "Fairness and formality: minimizing the risk of prejudice in alternative dispute resolution". Wisconsin Law Review, 1359.

EPP, C. R. (1998), The rights revolution: lawyers, activists, and supreme courts in comparative perspective. Chicago, University of Chicago Press.
FUKS, M. (2001), Conflitos ambientais no Rio de Janeiro: ação e debate nas arenas públicas. Rio de Janeiro, Ed. UFRJ.

GALANTER, M. (1983), "The radiating effects of Courts", in O. Boyum e L. M. Mather (eds.), Empirical theories about Courts, Nova York, Longman.

HANDLER, J. F. (1978), Social movements and the legal system: a theory of law reform and social change. Nova York, Academic Press.

HANNIGAN, J. (2009), Sociologia ambiental. Petrópolis, RJ, Vozes.

HILSON, C. (2009), "Framing the local and the global in the anti-nuclear movement: law and the politics of place". Journal of Law and Society, 36 (1): 94-109.

HOLZMEYER, C. (2009), "Human rights in an era of neoliberal globalization: the Alien Tort Claims Act and Grassroots Mobilization in Doe v. Unocal". Law \& Society Review, 43 (2): 271-304.

JASPER, J. (1997), The art of moral protest. Culture, biography, and creativity in social movements. Chicago, University of Chicago Press.

KECK, M. E. \& SIKKINK, K. (1998), Activists beyond borders: advocacy networks in international politics. Ithaca, NY, Cornell University Press.

KITSCHELT, H. P. (1986), "Political opportunity structures and political protest: anti-nuclear movements in four democracies. British Journal of Political Science, 16 (1): 57-85. Disponível em: <doi: 10.1017/S000712340000380X>. Acesso em: 25 jan. 2017.

KOERNER, A. (2012), "A história do direito como recurso e objetivo de pesquisa". Diálogos (on-line), 16 (2): 627-662.

LEMPERT, R. O. (1976), "Mobilizing private law: an introductory essay". Law \& Society Review, 11: 173-189.

LOPES, J. S. L. (2004), "A ambientalização dos conflitos em Volta Redonda", in H. Acselrad, Conflitos ambientais no Brasil, Rio de Janeiro, Relume Dumará.

(2006), "Sobre processos de "ambientalizaçáo" dos conflitos e sobre dilemas da participaçáo". Horizontes Antropológicos, 12 (25): 31-64. 
LOSEKANN, C. (2013), "Mobilização do direito como repertório de ação coletiva e crítica institucional no campo ambiental brasileiro". Dados, 56 (2): 311-349. Disponível em: <http://dx.doi. org/10.1590/S0011-52582013000200003>. Acesso em: 25 jan. 2017.

MACIEL, D. A. (2002), Ministério Público e sociedade: a gestão dos conflitos ambientais em São Paulo. Tese de doutorado em Sociologia, São Paulo, FFLCH, USP.

. (2011), "Ação coletiva, mobilização do direito e instituiçóes políticas: o caso da campanha da Lei Maria da Penha”. RBCS - Revista Brasileira de Ciências Sociais, 26 (77): 97-111.

MACIEL, D. A. \& KOERNER, A. (2002), "Sentidos da judicialização da política: duas análises". Lua Nova, 57: 113-133.

MACIEL, D. A. \& PRATA, P. S. B. (2011), "Movilización por nuevos derechos y cambio legal: la Campaña por la Ley Maria da Penha”. Revista de Ciencia Politica, 49 (1): 139-170.

MCCANN, M. (1991), "Legal mobilization and social reform movements: notes on theory and its application". Studies in Law, Politics, and Society, 11: 225-254.

. (2006a), "Law and social movements: contemporary perspectives". Annual Review of Law and Social Science, 2: 17-38

(2010), "Poder Judiciário e mobilização do direito: uma perspectiva dos 'usuários'". Revista Escola da Magistratura Regional Federal da $2^{a}$. Região/Emarf, seção especial, Anais do Seminário Nacional sobre Justiça Constitucional, pp. 175-196.

MCCANN, Michael W. (ed.) (2006b). Law and social movements. Londres, Ashgate.

MILNER, N. (1989), "The denigration of rights and the persistence of rights talk: a cultural portrait”. Law \& Social Inquiry, 14 (4): 631-675.

MINOW, M. (1987), "Interpreting rights: an essay for Robert Cover". Yale Law Journal, 96 (8): 1860-1915.

PEDRIANA, N. (2006), "From protective to equal treatment: legal framing processes and transformation of the women's movement in the 1960s”. American Journal of Sociology, 111 (6): 1718-1761.
POLLETTA, F. (2000), "The structural context of novel rights claims: Southern civil rights organizing, 1961-1966". Law and Society Review, 22 (5): 367-406.

ROSENBERG, G. N. (2008), The hollow hope: can courts bring about social change?. Chicago, University of Chicago Press.

RUCHT, D. (2008), "Movement allies, adversaries, and third parties", in D. A. Snow, S. A. Soule e H. Kriesi (eds.), The Blackwell Companion to Social Movements, Nova Jersey, John Wiley \& Sons.

SCHEINGOLD, S. A. (1974), The politics of rights: lawyers, public policy, and political change. New Haven, Yale University Press.

SCHNEIDER, E. M. (1986), "The dialectic of rights and politics: perspectives from the women's movement". N.Y.U.L. Review, 61: 589-652.

TARROW, S. (2009), O poder em movimento: movimentos sociais e confronto político. Petrópolis, RJ, Vozes.

TILLY, C. \& TARROW, S. (2006), Contentious politics. Oxford University Press.

TILLY, C.; TARROW, S. \& McADAM, D. (2001), Dynamics of contention. Cambridge University Press.

VANHALA, L. (2011a), Making rights a reality? Disability rights activists and legal mobilization. Cambridge University Press.

(2011b), "Social movements lashing back: law, social change and intra-social movement backlash in Canada", in Austin Sarat (ed.), special issue social movements/legal possibilities, Bingley, Emerald Group Publishing (Studies in Law, Politics and Society, 54).

ZEMANS, F. K. (1982), "Framework for analysis of legal mobilization: a decision-making model”. Law \& Social Inquiry, 7 (4): 989-1071.

. (1983), "Legal mobilization: the neglected role of the law in the political system". American Political Science Review, 77 (3): 690-703.

Legislaçôes, decisóes e processos judiciais

BRASIL. Decreto $n^{\circ} 3.871 / 2001$. Disciplina a rotulagem de alimentos embalados que contenham ou sejam produzidos com organismo 
geneticamente modificados, e dá outras providências. Revogado pelo Decreto n. 4.680, de 24/4/2003.

. Decreto n. 4.680/2003. Regulamenta o direito à informação, assegurado pela Lei $\mathrm{n}$. 8.078, de 11 de setembro de 1990, quanto aos alimentos e ingredientes alimentares destinados ao consumo humano ou animal que contenham ou sejam produzidos a partir de organismos geneticamente modificados, sem prejuízo do cumprimento das demais normas aplicáveis.

CTNBio. Resolução Normativa n. 4, de 16 de agosto de 2007. Dispóe sobre as distâncias mínimas entre cultivos comerciais de milho geneticamente modificado e não geneticamente modificado, visando à coexistência entre os sistemas de produção.

CTNBio. Resolução Normativa n. 5, de 12 de março de 2008. Dispóe sobre normas para liberação comercial de Organismos Geneticamente Modificados e seus derivados.

. Portaria MCT n. 979, de 26 de novembro de 2010. Altera o Regimento Interno da Comissáo Técnica Nacional de Biossegurança CTNBio.

DISTRITO FEDERAL. Seção Judiciária do Distrito Federal. Ação Civil Pública AC n. 1998.34.00.027682-0/DF. Requerente: IDEC - Instituto Brasileiro de Defesa do Consumidor. Requeridos: União Federal e Outros. Relator: Juiz Federal Titular da 6a Vara - Antônio Souza Prudente. Brasília/DF, 26 de junho de 2000.

. Tribunal Regional Federal da $1^{\text {a }}$ Regiáo. Ação Civil Pública AC n. 1998.34.00.0276820/DF. Apelantes: União Federal e Outros. Apelado: Idec -Instituto Brasileiro de Defesa do Consumidor. Relatora: Exma. Sra. Juíza Selene Maria de Almeida. Brasília/DF, 25 de fevereiro de 2002.

. Tribunal Regional Federal da $1^{\text {a }}$ Regiáo. Açáo Civil Pública AC n. 1998.34.00.0276820/DF. Apelantes: União Federal e Outros. Apelado: Idec - Instituto Brasileiro de Defesa do Consumidor e outros. Relatora: Exma. Sra. Desembargadora Selene Maria de Almeida. Brasília/DF, 7 de agosto de 2003.
. Seção Judiciária do Distrito Federal. Ação Civil Pública AC 2001.34.00.022280-6/DF. Requerente: Idec - Instituto Brasileiro de Defesa do Consumidor União Federal Requerido: Relatora: Exma. Sra. Juíza Selene Maria de Almeida. Brasília, 7 de agosto de 2003.

. Tribunal Regional Federal da $1^{\text {a }}$ Regiáo. Ação Civil Pública AC 2001.34.00.022280-6/ DF. Apelante: União Federal e Abia Apelado: Idec - Instituto Brasileiro de Defesa do Consumidor e Ministério Público Federal. Relatora: Exma. Sra. Desembargadora Federal Selene Maria De Almeida. Brasília/DF, 13 de agosto de 2012.

PARANÁ. Justiça Federal. Juízo Substituto da $11^{a}$ VF de Curitiba - Vara Ambiental, Agrária e Residual de Curitiba. Ação Civil Pública AC 2007.70.00.015712-8/PR. Autoras: Associaçáo Nacional de Pequenos Agricultores (Anpa), AS-PTA, Terra de Direitos, Idec. Rés: Uniāo Federal, Bayer, Syngenta, Monsanto e Associação Brasileira dos Produtores de Milho (Abramilho). Relatora: Juíza Federal Substituta Pepita Durski Tramontini Mazini. Curitiba, 26 de julho de 2010. 


\section{DIREITO, MOBILIZAÇÃO SOCIAL E MUDANÇA INSTITUCIONAL}

\section{Cristiana Losekann e \\ Luiza Duarte Bissoli}

Palavras-chave: Mobilização do direito; Movimentos sociais; Ambientalismo; Justiça ambiental; Transgênicos; Litígio estratégico; Ação Civil Pública.

$\mathrm{O}$ artigo analisa interaçôes entre os movimentos sociais e as instituiçôes jurídicas com o objetivo de observar efeitos gerados pelo uso do litígio como estratégia de ação coletiva em conflitos ambientais. A partir de dados empíricos e tendo em vista o debate teórico da Legal Mobilization Theory, apresentamos uma caracterização de tipos de efeitos: efeitos que alteram ou incrementam os próprios processos de mobilização social e efeitos sobre as instituiçôes. Argumentamos que a adoção de estratégias judiciais produz implicaçôes importantes sobre processos de mobilização social e de mudança institucional. As análises foram elaboradas a partir dos achados de duas pesquisas que investigaram o uso da Ação Civil Pública em conflitos ambientais. Uma levantou dados de conflitos ambientais em geral no Estado de Espírito Santo e na cidade do Rio de Janeiro e outra levantou dados da Campanha por um Brasil Livre de Transgênicos.

\section{LAW, SOCIAL MOBILIZATION AND INSTITUTIONAL CHANGE}

\author{
Cristiana Losekann e \\ Luiza Duarte Bissoli
}

Keywords: Legal mobilization; Social movements; Environmentalism; Environmental justice; Transgenics; Strategic litigation.

This article analyzes the interactions between social movements and juridical institutions in order to observe effects generated by the use of litigation as a strategy for collective action in environmental conflicts. From empirical data and in view of the theoretical debate on Legal Mobilization Theory, we present a characterization of some types of effects: effects that alter or increase the processes of social mobilization itself and effects on the institutions. We argue that the adoption of juridical and judicial strategies produces important implications on processes of social mobilization and institutional change. The analysis was based on the findings of two researches that had investigated the use of public civil action in environmental conflicts. One study collected data from environmental conflicts in general in the state of Espírito Santo and in the city of Rio de Janeiro, and the other from the Campaign for a Transgenic-free Brazil.

\section{DROIT, MOBILISATION SOCIALE ET CHANGEMENT INSTITUTIONNEL}

\section{Cristiana Losekann et \\ Luiza Duarte Bissoli}

Mots-clés: Mobilisation du droit; Mouvements sociaux; Environnementalisme; Justice environnementale; Cultures OGM; Litige stratégique; Action civile publique.

L'article analyse les interactions entre les mouvements sociaux et des institutions juridiques dans le but d'observer les effets engendrés par l'utilisation d'un litige en tant que stratégie d'action collective dans des conflits environnementaux. À partir de données empiriques et en considérant le débat théorique de la Legal Mobilization Theory, nous présentons une caractérisation des divers effets: ceux qui modifient ou augmentent les propres processus de mobilisation sociale et ceux qui atteignent les institutions. Nous affirmons que l'adoption de stratégies judiciaires produit des conséquences importantes sur les processus de mobilisation sociale et de changement institutionnel. Les analyses ont été compilées à partir des résultats de deux études qui enquêtent l'utilisation d'une action civile publique en cas de conflits environnementaux. L'une a compilé les données de conflits environnementaux en général dans l'état d'Espírito Santo et dans la ville de Rio de Janeiro et l'autre, des données de la campagne "pour un Brésil sans transgéniques". 